\title{
Evidence-based designation of development regions in Romania
}

József Benedek Public debates on the regional dimension of Babeş-Bolyai University, societal organisation are marked by a series of Romania stereotypes originating from the lack of E-mail: jozsef.benedek@ubbcluj.ro knowledge of this phenomenon. For this reason, this study combines the concepts of ho-

Ibolya Török mogeneity and heterogeneity with specific Babeș-Bolyai University, spatial structures (core-periphery structures) in Romania the designation of development regions E-mail: ibolya.torok@ubbcluj.ro (NUTS 2 level) in Romania. Its aim is to provide scientifically sound alternatives for the

Csongor Máthé designation of development regions. Babes-Bolyai University, The main contribution of the paper is to inRomania troduce three alternative scenarios for the de-

E-mail: csongor.mathe@ubbcluj.ro limitation of development regions.

\section{Keywords:}

homogeneity, heterogeneity, core-periphery structures, regionalisation Romania

\section{Introduction}

The question of the regional shaping of society has received substantial academic attention during the last two decades in very different spatial, political and economic contexts (Săgeată 2004, Benedek-Jordan 2007, Lentz et al. 2007, Máté et al. 2011, Ertugal-Dobre 2011, Benedek-Bajtalan 2015, Keating 2015, Benedek 2016). Additionally, regional agenda became an influential subject for state and party politics in societies with high ethnocultural diversity, including Romania. On the one hand, we can observe that the most recent examples of the British or Italian devolution are related to the general concept of state modernisation and the recognition of ethnocultural and regional diversity. On the other hand, the very recent case of the Catalan independence movement exemplifies the strong limits of the so-called 'Europe of regions' model. Moreover, the question of regionalisation is not only 
viewed as a scientific or political one, but is also related to increasing expectations of better-tailored public policies and improved economic governance (RodríguezPose-Gill 2005, Benedek-Lembcke 2017).

The post-communist establishment of public administration in Romania has strengthened sub-national levels of governance. The discussions about the role of the development regions (created in 1998) and about regionalisation and the reshaping of the administrative-territorial units in Romania, came into a new light very recently. In 2011, when former state President Traian Basescu launched a political project on regionalisation, and in 2013, when the then ruling coalition government Social Liberal Union (USL) instituted a new project on regionalisation. Both projects have triggered a wide debate in Romania on the scope and content of regionalisation, with a significant number of alternatives developed by different scientists, politicians, and mass media representatives (for more details, see Benedek-Bajtalan 2015). The regionalisation discourses and projects referred to both new administrative-territorial divisions at the regional level, as well as the decentralisation of administrative competencies from the state to the regional level. This article contributes to these discussions and is based on comprehensive research made in 2013 and published in Romanian in the same year (Benedek et al. 2013). This paper addresses the following question: what is the adequate way to designate development regions in Romania? It would not be possible to propose an optimum solution for the designation of development regions due to the complexity. However, we provide an evidence-based alternative, which relies on the combination of different tools and methods of regional science and spatial analysis.

The question raised in this paper is of major interest for two reasons (Benedek 2015): the paper offers different scenarios for the adequate spatial scale and form of 1. the state's economic policy design and implementation in fields like infrastructure planning, the labour market, or innovation; 2. management for cultural and ethnic diversity. Therefore, our study addresses the question of area designation for development purposes combining the above-mentioned perspectives. This line of questioning and argumentation concurs with the major findings of the study of Lineira and Cetra (2015), where economy and national identity - alongside party politics are considered the main factors behind regionalisation in Europe.

The article proceeds as follows: first, we present some theoretical and methodological considerations. Second, we focus on ethnocultural and economic homogeneity/heterogeneity criteria in determining the structural regions in Romania. Third, we present different proposals for the reorganisation of the development regions. Finally, we draw some conclusions from the discussion.

Regional Statistics, Vol. 8. No. 1. 2018: 120-140; DOI: 10.15196/RS080105 


\section{Homogeneity/heterogeneity criteria for the designation of structural regions}

This paper's methodology focuses on the delimitation of homogeneous (structural) regions based on the similarity principle, that is, a homogeneous region is determined by the individuality of its structure (for more details see Benedek 2004, 2006). One can speak of homogeneity only in the case when similar or almost similar elements characterise a certain territory continuously and permanently. Homogeneous regions are those that can be delimited based on internal similarities and can be described using one (some) uniformity index (indices) (Hoover-Giarratani 1999). When delimiting the homogeneous regions, we can use several structural indicators and their combinations. Depending on the manner in which these indicators and the connections between them are determined, we can specify several homogeneous regions. To delimit the homogeneous regions, certain structural characteristics are used, or their aggregate expression, in the form of some indices. One can take into account one or several structural characteristics. In the last case, structural characteristics are combined as complex indices. Concerning the delimitation of the homogeneous regions, we mention two essential methodological problems (Weichart 1996): 1. Regionalisation is strongly influenced by the spatial reference units used for the representation of the structural characteristics; 2. Regionalisation is also influenced by the construction of value ranges and their corresponding categories. To choose the value ranges, different statistical techniques are used, but they are not generally valid as they prescribe only certain range construction rules. It follows from the above that regionalisation based on the homogeneity principle is, to a certain extent, the result of deploying delimitation methodology, as the homogeneous regions are often methodological constructions (Benedek 2004). However, this is frequently used, as it represents the only technical way of representing the spatial dispersion of the values of some important parameters.

Following the arguments presented in the introduction, we will now examine the ethnocultural and economic diversity of Romania, which is considered as crucial for the designation of development regions.

\section{Ethnocultural homogeneity/heterogeneity}

We will further analyse the manner of distribution of population belonging to various ethnic and religious groups. The most important characteristic in the territorial distribution of an ethnocultural community is alternating the high ethnic-cultural diversity areas with other ethnically or religiously homogeneous areas, resulting from historical evolution (Pénzes et al. 2018). The ethnic fragmentation of a country may be calculated and compared using the ethnic differentiation index (EDI) (Muir 1981). The lower the value of the index, the higher the ethnic differentiation. The index of a perfectly homogeneous territory equals 100. In this analysis, only those ethnic groups where the population represented 1,500 persons maximum 
were considered. Based on this formula, the religious fragmentation index (RFI) was also calculated. The lower the value of RFI, the higher the religious fragmentation. The value of the EDI at the national level, according to the 2002 census is 81, which does not show major changes as compared to the 1992 census, when Romania's index was 80 . At the commune level, there are several perfectly homogeneous localities but, also, territories where the ethnic differentiation index barely reaches 30. This is the case of the Suplacu de Barcău (Berettyószéplak) commune, where ethnic diversity is determined by the high percentage of the Roma and Slovak population besides the Romanian and Hungarian population (see Figure 1).

Figure 1

The ethnic differentiation index in Romania at the local level, 2002

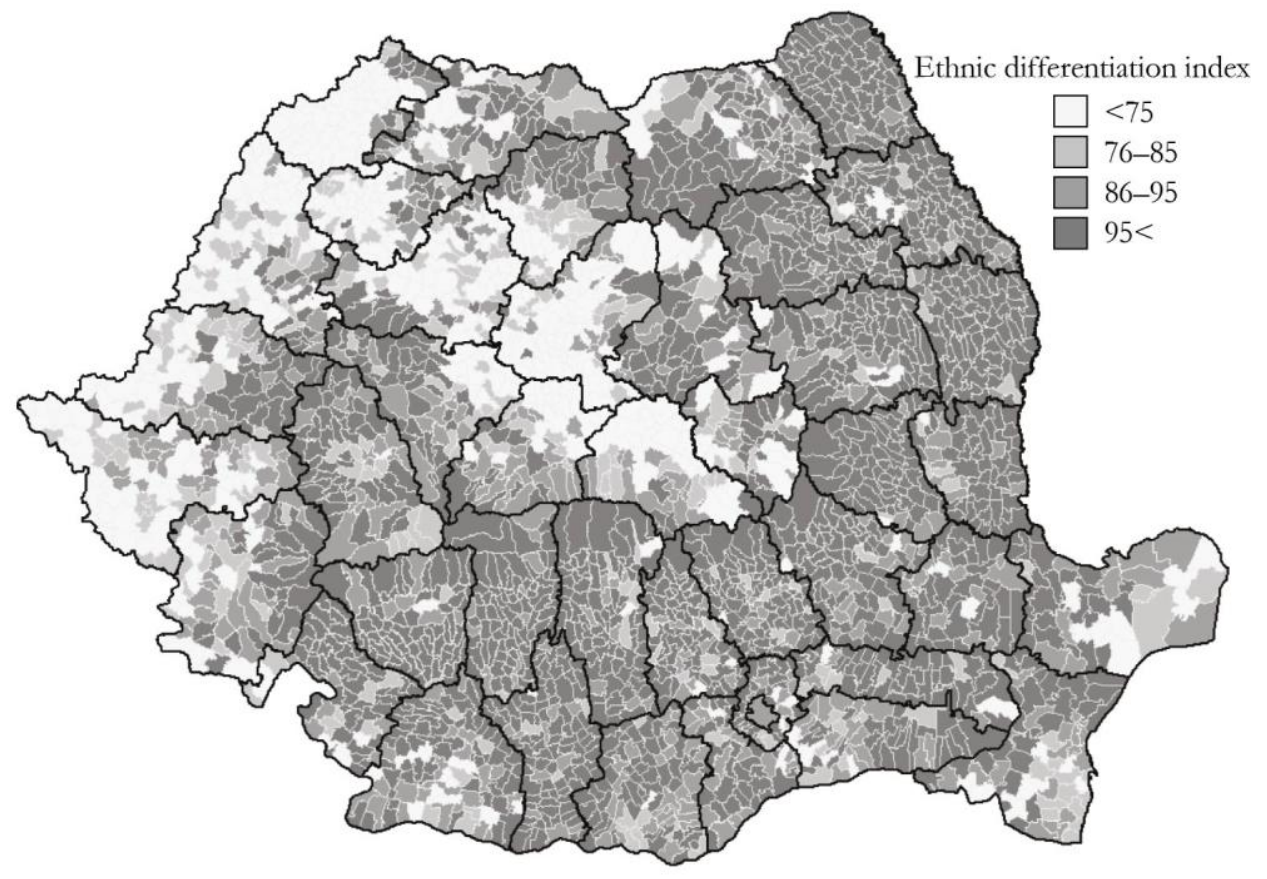

Source: Own elaboration based on INSSE's (Romanian National Institute of Statistics) 2002 Census data.

At the county level, the lowest values of the EDI are recorded in Mureş (44), Satu Mare (47) and Bihor (51), while the highest are in Vâlcea, Botoşani and Vaslui (98). From this perspective, the counties belonging to the historical region of Banat represent the territory with the highest level of ethnic diversity in Romania (see Figure 2).

EDI reflects, to a larger extent, both the size and number of the ethnic groups as compared to the percentage of the majority population. However, it reflects only

Regional Statistics, Vol. 8. No. 1. 2018: 120-140; DOI: 10.15196/RS080105 
the major groups, as the small ones do not influence this indicator much (Bodocan 1997). For example, the Caraş-Severin County and Bucharest are composed of 8 ethnic groups of more than 1,500 persons. However, the value of the ethnic differentiation index is higher than that recorded in Mureş County (78 and 94, as compared to 44), composed of only 3 ethnic groups with more significant percentages than the first two cases. Furthermore, in the 2 Székely counties, the ethnic homogeneity index is 60 in Covasna and 73 in Harghita, as the percentage of Hungarian population is $74 \%$ and $85 \%$, respectively. At the same time, it may be noted that EDI has lower values in those counties where national minorities are sporadically present.

The ethnic differentiation index

Figure 2

in Romania at the county level, 2002

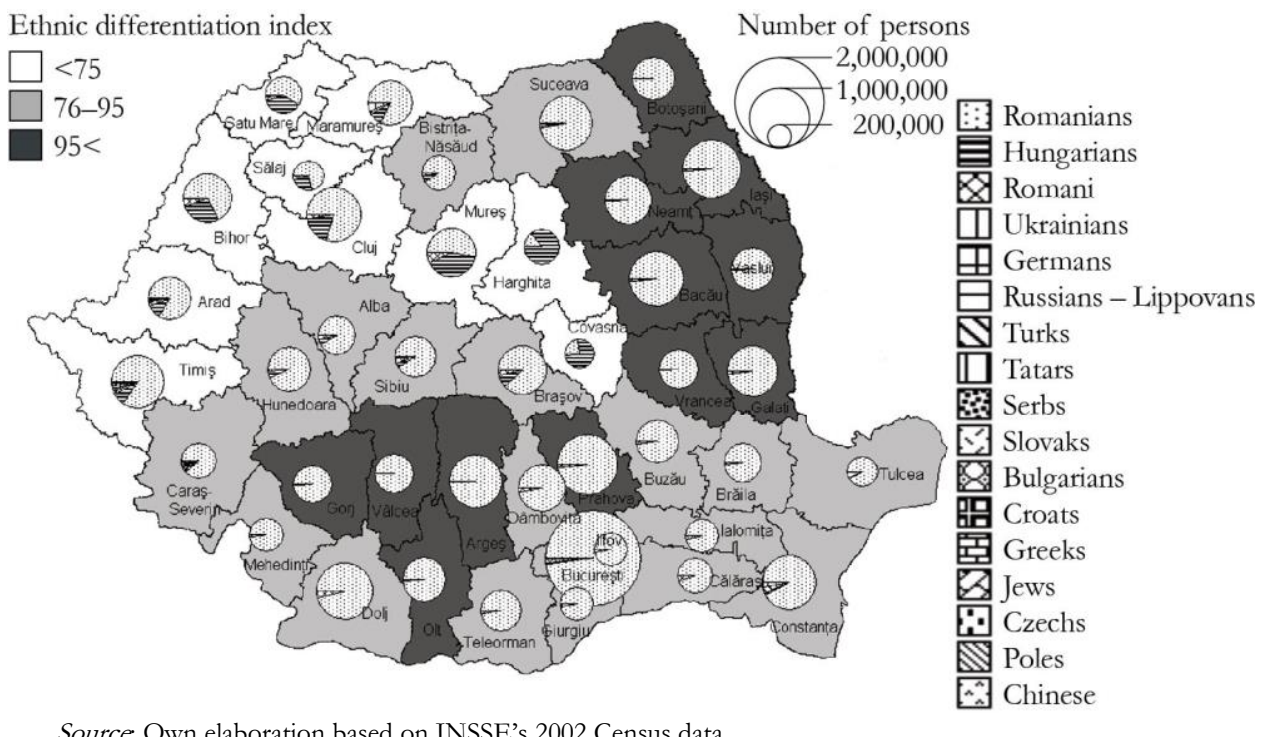

Source: Own elaboration based on INSSE's 2002 Census data.

The religious structure of the population marks another component of the cultural differences. In the 2002 census, $99.8 \%$ of the country's population declared having a certain religion (confession), $0.1 \%$ declared they were atheists or with no religion, while the remaining $0.1 \%$ refused to declare their religious membership. According to the 2002 census, the Orthodox population was predominant (representing $86.8 \%$ ). The Romano-Catholics represented $4.7 \%$ of the total, the Reformed $3.2 \%$ and the Pentecostals 1.5\%. The percentage of the other religious confessions was less than $1 \%$. Their ethnic structure influences the confessional structure of the counties: the Romanians belong mainly to the Orthodox confession, and the Hungarian population belongs to Romano-Catholicism, Reformed religion, Unitarianism 
and partially to Evangelicalism. As shown in Figures 3 and 4, the religious diversity of the country far exceeds its ethnic diversity, being much higher in the counties of Transylvania.

The counties of Covasna, Satu Mare and Mureş stand out, with the lowest values of the RFI (below 40), while the counties of Vâlcea and Olt have registered values over 98. This reflects the more or less significant percentage of the population groups belonging to a religious cult. The religious diversity of the localities reflects this situation without changing the county image drastically (see Figures 3 and 4).

\section{The religious differentiation index}

Figure 3

in Romania at the local level, 2002

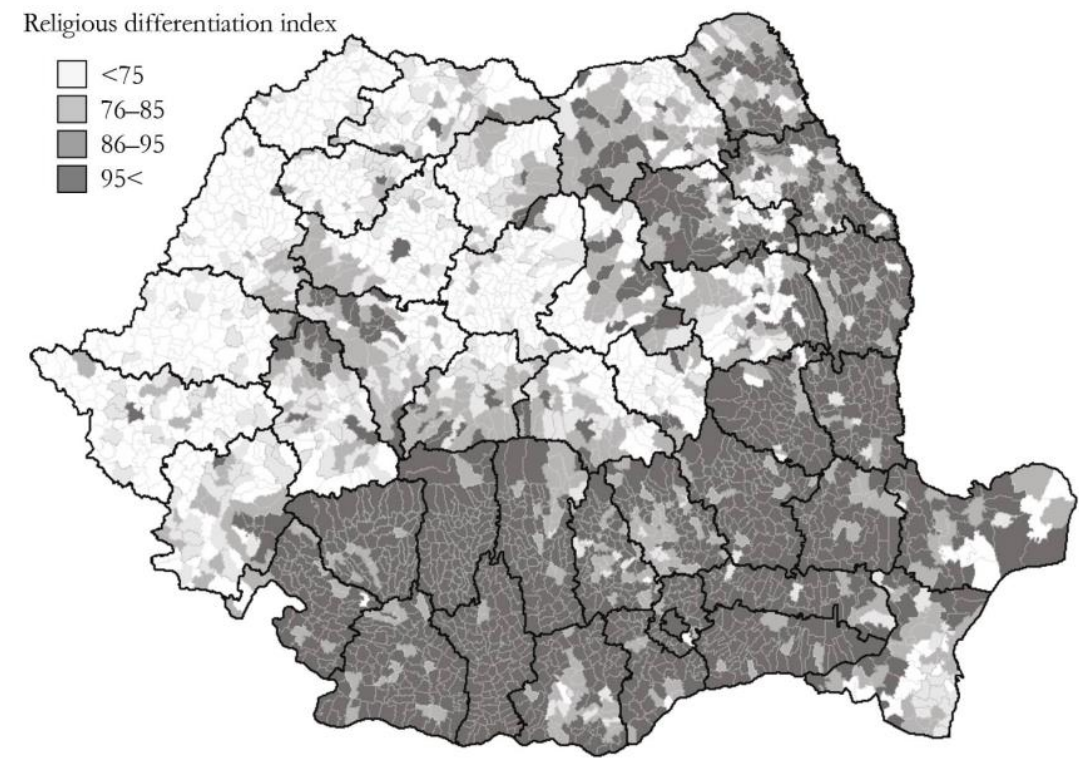

Source: Own elaboration based on INSSE's 2002 Census data. 
The religious differentiation index and the religious structure

Figure 4 in Romania at the county level, 2002

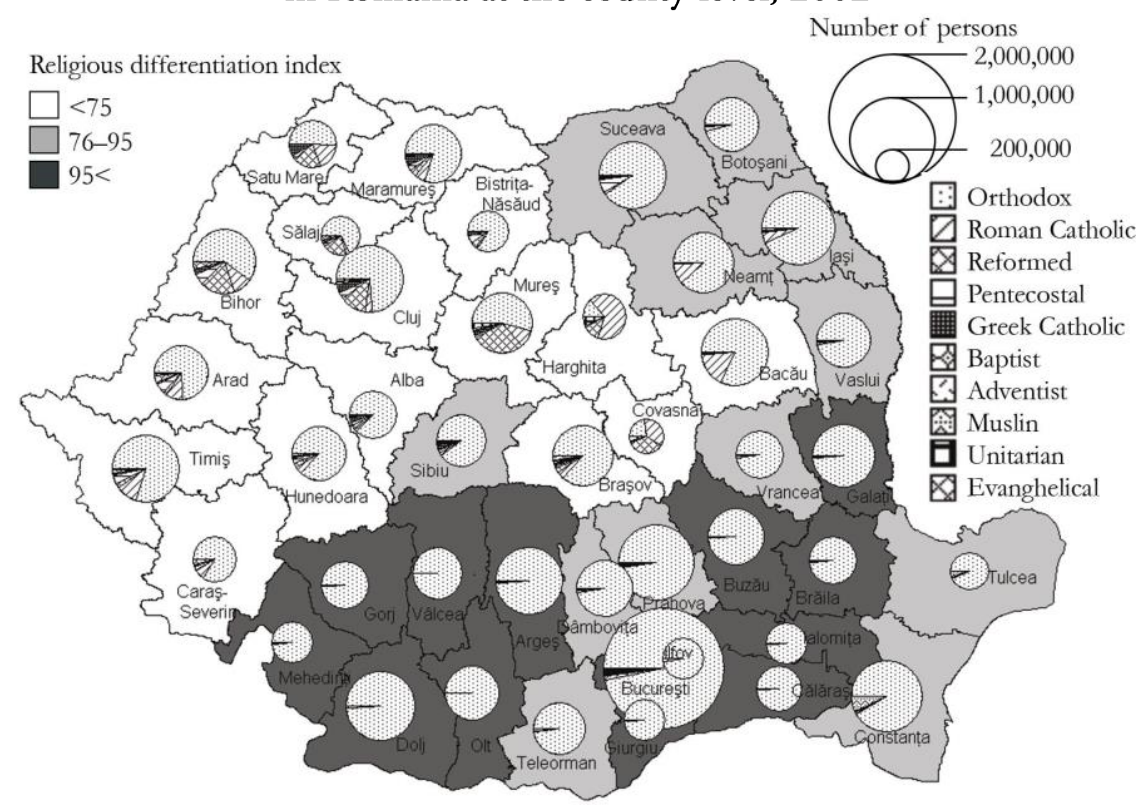

Source: Own elaboration based on INSSE's 2002 Census data.

\section{Economic homogeneity/heterogeneity}

The economic homogeneity/heterogeneity is outlined by using gross domestic product (GDP) per capita data available in Romania at NUTS 2 and NUTS 3 levels. At the NUTS 3 level, the economic output is highly concentrated in the administrative centres of the counties (Benedek-Kurkó 2012). The homogeneity/heterogeneity is further analysed on economic development (GDP per capita), using the potential model. This method is based on the physical analogies from the spatial model category and, at the same time, enables the general description of the country's economic space structure, the territorial distribution of the areas with various degrees of development. The essence of the method is that it explains the 'intensity' of the social-economic phenomena as it takes into consideration the value of the analysed phenomenon belonging to the territorial units, that is, the distance between them. At the same time, the potential model highlights the disadvantaged areas from the economic development point of view. This model enables us to specify the more general aspects; the economic core of the country becomes visible, and we can delimit the transition area/areas, as well as the disadvantaged, peripheral areas (Nagy 2004).

According to the model, the best-positioned regions (with the highest potential) are those that concentrate the major economic force and/or are located near the 
main economic power cores. Consequently, in determining the economic potential of one territorial unit, besides its economic performance, an important role is also played by the other analysed territorial units. It is possible that a region of relatively low economic power will have a high economic potential if economically powerful neighbours surround it. By contrast, there are also cases where a region of significant economic power has moderate potential, but regions of a weaker economic situation surround it and it is far from the key sectors of the national economy (Nagy 2004). Thus, the potential may be divided into three components: intrinsic potential, internal potential, and external potential.

The intrinsic potential is $P_{\text {intrinsic }}\left(A_{i}\right)=\frac{M_{i}}{d_{i i}^{b}}$, where $P\left(A_{i}\right)$ is the potential of the point $A_{i}, M_{i}$ stands for the mass of territory points taken into consideration, $d$ denotes the distance between two points, and is equal to $\left(T_{i} / \Pi\right)^{0.5} / 3$ ( $T_{i}$ is the area of the analysed territory), and $b$ is a constant.

The internal potential is $P_{\text {internal }}\left(A_{i}\right)=\sum_{j=1}^{n} \frac{M_{j}}{d_{i j}^{b}}$, while the external potential is $P_{\text {external }}\left(A_{i}\right)=\sum_{k=1}^{n} \frac{M_{k}}{d_{i k}^{b}}$

The allocation of some territorial units determines the intrinsic potential to each point (e.g. in the case of the localities, their size) but, after that, the distance to the unit will be calculated based on its size. When we determine the internal potential, we need to calculate the value of the effect of some analysed territorial units on the other territorial units. The effect depends on the size of the analysed points, respectively on the distance calculated to the given territorial unit; the larger the territorial unit and the closer in space, the higher the value. The external potential is practically identical to the internal potential but, in this case, we can also take into consideration the effect of the territorial units located outside the analysed area (Nemes Nagy 2005, Pénzes 2010).

The analysis of the core and peripheral relationship reveals that - despite the eccentric geographic location - Bucharest occupies a special place in the spatialeconomic structure of the country (see Figure 5). Its economic contribution exceeds twice the average national value $(23 \%$ in 2008 , when the population concentration was only $9 \%$ ). At the same time, in Bucharest, most of the small and medium-sized enterprises (SMEs) $(21.5 \%$ of the total SMEs) exist, which stand out both by a large number of employees in the research and development sector (R\&D) and by the high concentration of foreign direct investments (FDI). 
The distribution of counties by the potential model, 2002

Figure 5

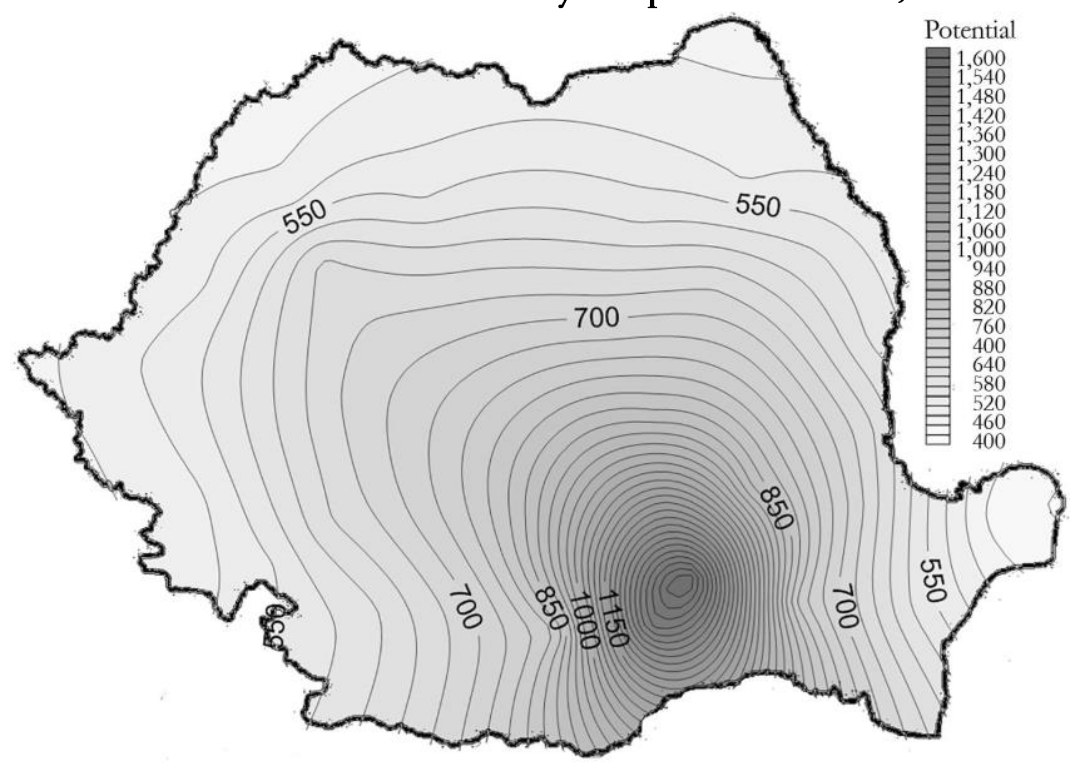

Note: The potential values are based on GDP per capita.

Source: Own elaboration based on Eurostat data.

The western regions - due to their location - may be considered more dynamic than external peripheries; the latter instead characterises some counties in Moldavia and Muntenia, composing homogeneous regions because of the lower level of development. The situation of the counties in the Seklerland is not favourable, as these counties are considered, from many points of view and according to the analysis of many indicators, to be internal peripheries dependant on their surrounding areas. The core-periphery relationship from the perspective of geographical location not only refers to a privileged area or a peripheral locality, but also to the presence or lack of economic activities, that is, it is identical to accessibility (Nagy 2004).

Starting from the fact that there is a relatively close relationship between the unemployment rate and the GDP per capita $(r=-0.60)$, it is important to also examine the situation of counties depending on the unemployment rate and the positions they occupy in the spatial hierarchy of development. According to the two indicators, $20 \%$ of the counties have a relatively high level of development, correlated with a low unemployment rate. Almost $15 \%$ of the counties fall into the category with a low level of development and, implicitly, with a high unemployment rate. As shown in Table 1, Bucharest, the counties of Ilfov, Timiş, Cluj, Constanța, Sibiu, Arad, Bihor and Braşov compose the dynamic regions of Romania, while the counties of Vaslui, Teleorman, Buzău, Olt and Mehedinţi constitute the most socially and economically peripheral regions (see Table 1).

Regional Statistics, Vol. 8. No. 1. 2018: 120-140; DOI: 10.15196/RS080105 
The classification of counties by GDP per capita and the unemployment rate, 2011

\begin{tabular}{|c|c|c|c|c|}
\hline \multicolumn{5}{|c|}{ GDP per capita, PPP } \\
\hline \multirow{4}{*}{ 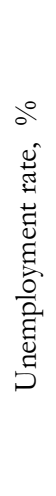 } & & high $(>9,833)$ & $\begin{array}{l}\text { moderate }(8,700- \\
9,833)\end{array}$ & low $(<8,700)$ \\
\hline & low $(<5.2)$ & $\begin{array}{l}\text { Bucharest, Ilfov, } \\
\text { Timiş, Cluj, Constanţa, } \\
\text { Sibiu, Arad, Bihor, } \\
\text { Braşov }\end{array}$ & & $\begin{array}{l}\text { Suceava, Maramureş, } \\
\text { Satu Mare, Botoşani, } \\
\text { Bistrița-Năsăud }\end{array}$ \\
\hline & moderate (5.2-6.4) & $\begin{array}{l}\text { Tulcea, Argeş, } \\
\text { Prahova }\end{array}$ & $\begin{array}{l}\text { Vâlcea, Iaşi, Caraş- } \\
\text { Severin, Giurgiu, } \\
\text { Brăila, Hunedoara, } \\
\text { Mureş }\end{array}$ & $\begin{array}{l}\text { Neamţ, Vrancea, } \\
\text { Bacău, Călăraşi }\end{array}$ \\
\hline & high $(>6.4)$ & Alba, Gorj & $\begin{array}{l}\text { Dolj, Covasna, Har- } \\
\text { ghita, Ialomiţa, Sălaj, } \\
\text { Dâmboviţa }\end{array}$ & $\begin{array}{l}\text { Vaslui, Buzău, Tele- } \\
\text { orman, Mehedinți, } \\
\text { Galați, Olt }\end{array}$ \\
\hline
\end{tabular}

Note: PPP - purchasing power parity.

Source: Own elaboration based on INSSE (2013a) data.

A special case is represented by the counties of Alba and Gorj, which fall under the category of counties with a high GDP per capita and, at the same time, with high unemployment rates. The massif privatisation and economic restructuration of the mining regions following 1997 have led to the loss of jobs for a significant number of persons in these counties.

\section{Proposals for the reorganisation of the development regions}

\section{The development regions in Romania}

The regional level in Romania does not represent an administrative level per se, as it was formed in 1998 by the multi-criterial grouping of several counties into eight development regions. The legislative framework for the operation of these regions is provided by Law No. 151 of 1998 on the regional development in Romania. The Romanian development regions are not political entities, have low decisionmaking power and limited financial resources. Consequently, the most important stakeholder of the regional development in Romania remains the state that controls and directs, to a significant extent, the resources allocated to development. New projects on reshaping this institutional and territorial arrangement are widely debated and discussed regarding Romanian, as presented in the introduction. Thus, the following sections attempt to develop further empirical evidence for the designation of development regions with a combination of homogeneity and functional criteria of area designation.

Regional Statistics, Vol. 8. No. 1. 2018: 120-140; DOI: 10.15196/RS080105 


\section{Designation of development regions based on economic homogeneity/heterogeneity}

The multidimensional analysis (ethnic-cultural and economic) of the homogeneity/heterogeneity degree (in section two) offered a diversified image of the counties and regions that cannot provide the necessary scientific arguments to designate regions when we include these in the same regional counties with a variable degree of homogeneity. The literature does not offer us ready-made solutions. Therefore, we propose designating regions with a core-periphery structure where one or two counties with a higher degree of economic development represent the core-area of the region to which a variable number (depending on ethnocultural characteristics) of counties with semi-periphery or periphery status are added. Based on Table 1, we have classified counties into core, semi-core, semi-periphery, and periphery structures (see Table 2). The positioning of the counties according to Table 2 is in line with our recent findings on core-periphery structures in Romania (for detail, see Benedek 2015). All counties in the 'core' category have a high demographic potential, a high education index and a high percentage of the population occupied in the secondary and tertiary sector (see for details Benedek et al. 2013).

Using the status of each county in Table 2, we applied a principle that may be called the principle of combining areas of various degrees of homogeneity. The outcome is a new scenario for redrawing the development regions in Romania, which includes ten regions (see Figure 6), instead of the existing eight. It presents a series of not inconsiderable advantages: a larger number of regions and, implicitly, reduced area and the number of inhabitants create better conditions for the management of regional problems; stronger identification of the population with the delimited region; higher accessibility of the regional core areas; building of the regions around core-periphery spatial structures, which are more competitive and much easier to designate than regions defined according to homogenous criteria.

Table 2

Core, semi-core, semi-periphery and periphery counties

\begin{tabular}{|c|c|c|c|}
\hline Core & Semi-core & Semi-periphery & Periphery \\
\hline \multicolumn{4}{|c|}{ counties } \\
\hline $\begin{array}{l}\text { Bihor, Cluj, Sibiu, } \\
\text { Constanța, Prahova, } \\
\text { Ilfov, Bucharest, Ar- } \\
\text { ad, Timiş }\end{array}$ & $\begin{array}{l}\text { Braşov, Argeş, Alba, } \\
\text { Gorj, Hunedoara }\end{array}$ & $\begin{array}{l}\text { Bistrița-Năsăud, Sălaj, } \\
\text { Mureş, Brăila, Tulcea, } \\
\text { Vâlcea, Iaşi, Covasna, } \\
\text { Harghita, Bacău, Galați, } \\
\text { Dâmboviţa, Dolj, Caraş- } \\
\text { Severin }\end{array}$ & $\begin{array}{l}\text { Neamț, Maramureş, Satu } \\
\text { Mare, Botoşani, Suceava, } \\
\text { Vrancea, Călăraşi, Giur- } \\
\text { giu, Ialomița, Olt, Vaslui, } \\
\text { Buzău, Teleorman, Me- } \\
\text { hedinți }\end{array}$ \\
\hline
\end{tabular}

Regional Statistics, Vol. 8. No. 1. 2018: 120-140; DOI: 10.15196/RS080105 
The grouping of counties into development regions

Figure 6 by economic homogeneity/heterogeneity

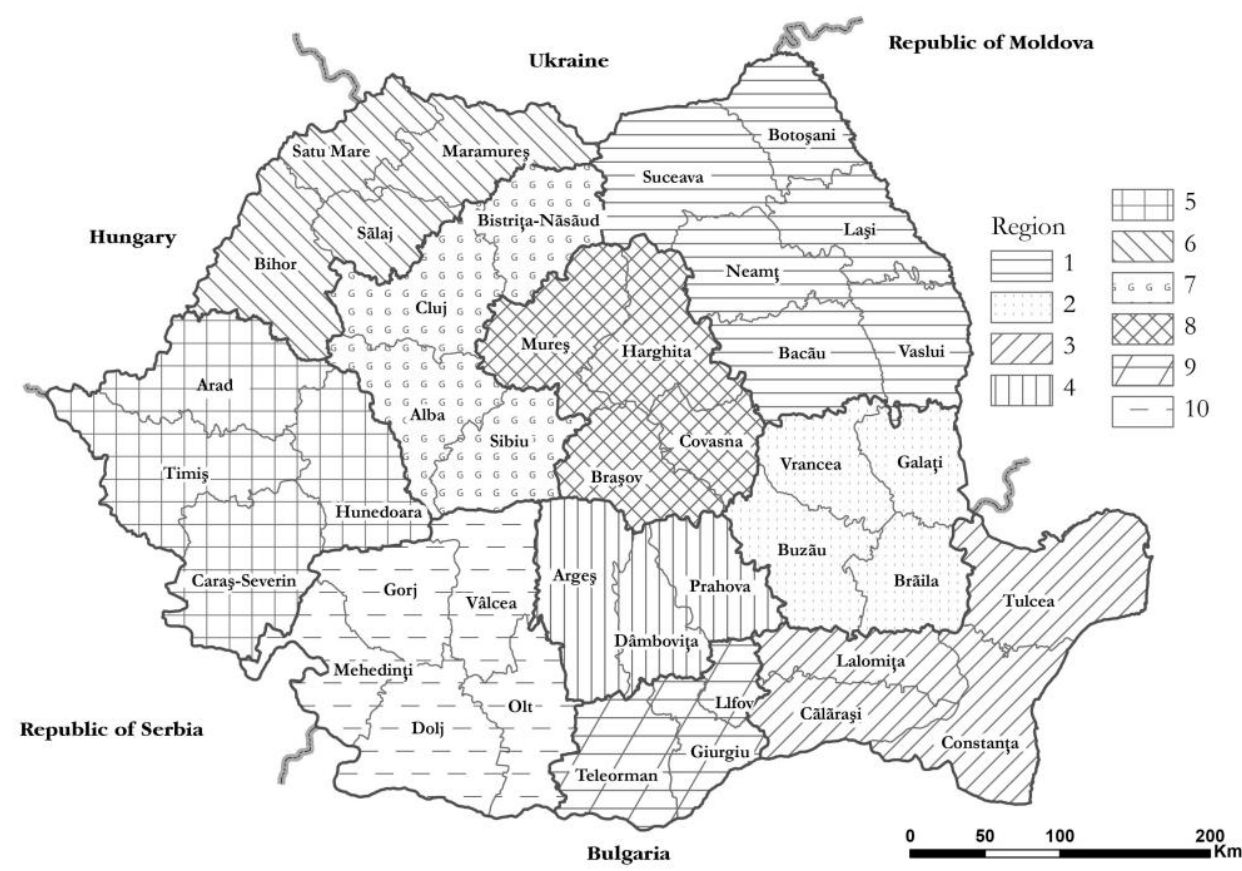

Designation of development regions based on ethnocultural homogeneity/heterogeneity

Ethnocultural diversity offers another variant for the organisation of the development regions. Figures 1-4 provide us with an image of cultural homogeneity/heterogeneity, expressed by two dimensions: ethnic and religious. In this situation, the optimum variant from the ethnocultural perspective is in the grouping of counties of high cultural heterogeneity - with possibilities for the efficient use of the cultural diversity as a development resource - within the same development regions. This logic would imply three such territorial groups: the counties of Mureş, Harghita and Covasna, then the counties of Bihor, Satu Mare and Sălaj and, finally, the counties of Constanța and Tulcea. Furthermore, this logic would not particularly affect the structure of the other development regions, which would remain mostly the same, with the above exceptions (see Figure 7).

Regional Statistics, Vol. 8. No. 1. 2018: 120-140; DOI: 10.15196/RS080105 
The grouping of counties into development regions

Figure 7 by ethnocultural homogeneity/heterogeneity

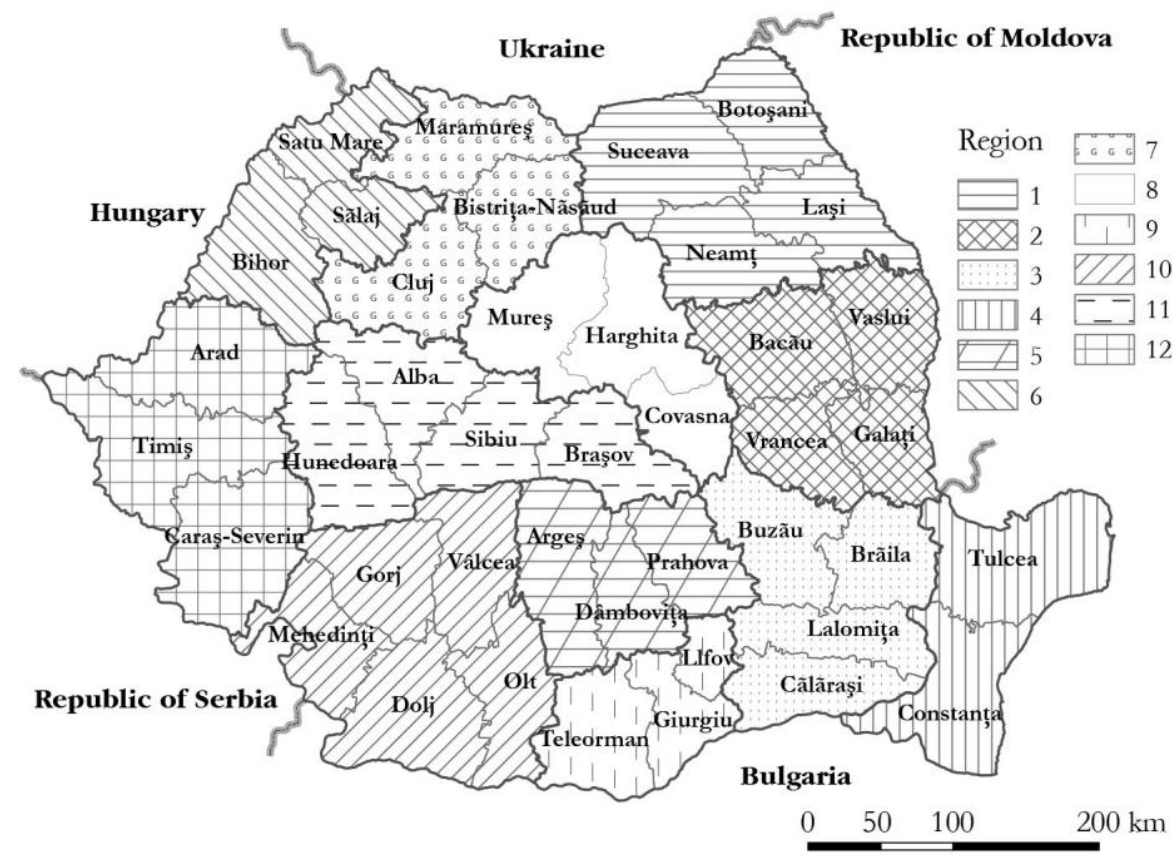

The adjustments performed pursue the application of the cultural criterion, more specifically, the belonging of counties to various historical-geographical regions.

\section{Designation of development regions based on complex homogeneity criteria}

In most cases, the classification of the regions and definition of the types of regions can be based on some complex, multidimensional criteria and indicators. Thus, the most important mathematical-statistical method for the multidimensional classification is the cluster analysis, which can be used in cases when we attempt to group and classify similar elements from a certain perspective. The main objective is to classify the individual territories - based on the variables used - into homogeneous groups, thus leading to downsizing. Thus, analysis can be carried out without preliminary information on the characteristics of the group but, following the analysis, the types of units will be formed based on the classification. This analysis is the best method to understand the formation of various typologies. The cluster analysis is most successful when the counties in a certain group have a high degree of similari-

Regional Statistics, Vol. 8. No. 1. 2018: 120-140; DOI: 10.15196/RS080105 
ty. After the completion of the cluster analysis, one unit will fit into one single group and will be different from the units that are classified in the other clusters (Han-Kamber 2004, Füstös et al. 2004, Székelyi-Barna 2005). For the grouping of similar counties based on the cluster analysis, the following indices were taken into consideration: Rural population (\%), 2013; GDP per capita (PPP), 2011; Unemployment rate (\%), 2013; Population occupied in R\&D per 1,000 inhabitants, 2013; FDI/inhabitant (EUR), 1990-2012; Number of vehicles per 1,000 persons, 2013; Population occupied in the primary sector (\%), 2013; Number of physicians per 1,000 persons, 2013; Number of higher education graduates (\%), 2013; SME/1,000 inhabitants, 2013.

In the first phase, Dolj stands out from the rest of the counties. While the amount of the foreign direct investments is among the lowest at the country level, concerning the percentage of higher education graduates, the percentage of the population occupied in $\mathrm{R} \& \mathrm{D}$, the number of physicians per 1,000 persons, as well as the number of vehicles per 1,000 persons, extremely favourable values are recorded. Dolj also stands out by the high value of its unemployment rate.

In the following phases, Ilfov and Iaşi stand out from the rest of the counties, together with the country's capital city. If the separation of Bucharest may be explained by the fact that all the analysed indicators recorded more favourable values, Ilfov county is espeeecially different because of its favourable position regarding GDP per capita and foreign direct investments. Conversely, Iaşi county stands out because of the high percentage of higher education graduates, as well as the number of physicians per 1,000 persons.

In the fifth phase, another group of counties stand out: to the counties in Moldova (Botoşani, Suceava, Neamţ, Vaslui, and Vrancea) the following are added: Ialomița, Călăraşi, Giurgiu, Teleorman, Buzău and Dâmbovița from Muntenia and the counties of Olt and Mehedinți from Oltenia. As may be seen, these are less developed counties, with high unemployment rates, which are also ranked lower regarding foreign direct investments, GDP, number of SMEs and vehicles per 1,000 persons. In conclusion, these counties compose a distinctive group with multiple disadvantages.

In the sixth phase of the cluster analysis, those counties stand out that, paradoxically, though they have a higher level of economic development, record high rates of unemployment. These are Hunedoara, Arad, Constanţa, Sibiu and Braşov, where, following the deindustrialisation process, even at the beginning of the twenty-first century, the negative effects of industrial restructuring are still felt.

In the following phase, two clusters have occurred, represented by the counties of Timiş and Cluj, with a high percentage of higher education graduates and a high rate of the population occupied in $\mathrm{R} \& \mathrm{D}$. At the same time, a series of indicators, such as the number of SMEs per 1,000 inhabitants, GDP per capita and FDI per capita or the population occupied in the tertiary sector also record high values in the above-mentioned counties.

Regional Statistics, Vol. 8. No. 1. 2018: 120-140; DOI: 10.15196/RS080105 
In the following phase, the counties of Iaşi, Dolj, Galați and Argeş stand out. These counties record favourable values for only a few of the selected indicators: Iaşi and Dolj for the number of vehicles per 1,000 persons, the percentage of higher education graduates and the percentage of the population occupied in R\&D. Argeş and Galați fall under this class due to the high volume of foreign direct investments.

In the last phase, eight clusters are highlighted: including the counties of Ialomiţa and Mehedinți, another group composed of the counties of Botoşani, Vaslui, Călăraşi, Giurgiu and Teleorman are highlighted. The low level of development, the low quality of sanitary services and lack of diversification of the economic structures (high percentage of the persons occupied in the primary sector) have contributed to the emigration of a large part of the population, leaving behind highly rural communities. As a whole, these counties compose the group of counties with multiple disadvantages (see Figure 8).

The grouping of counties based on cluster analysis

Figure 8

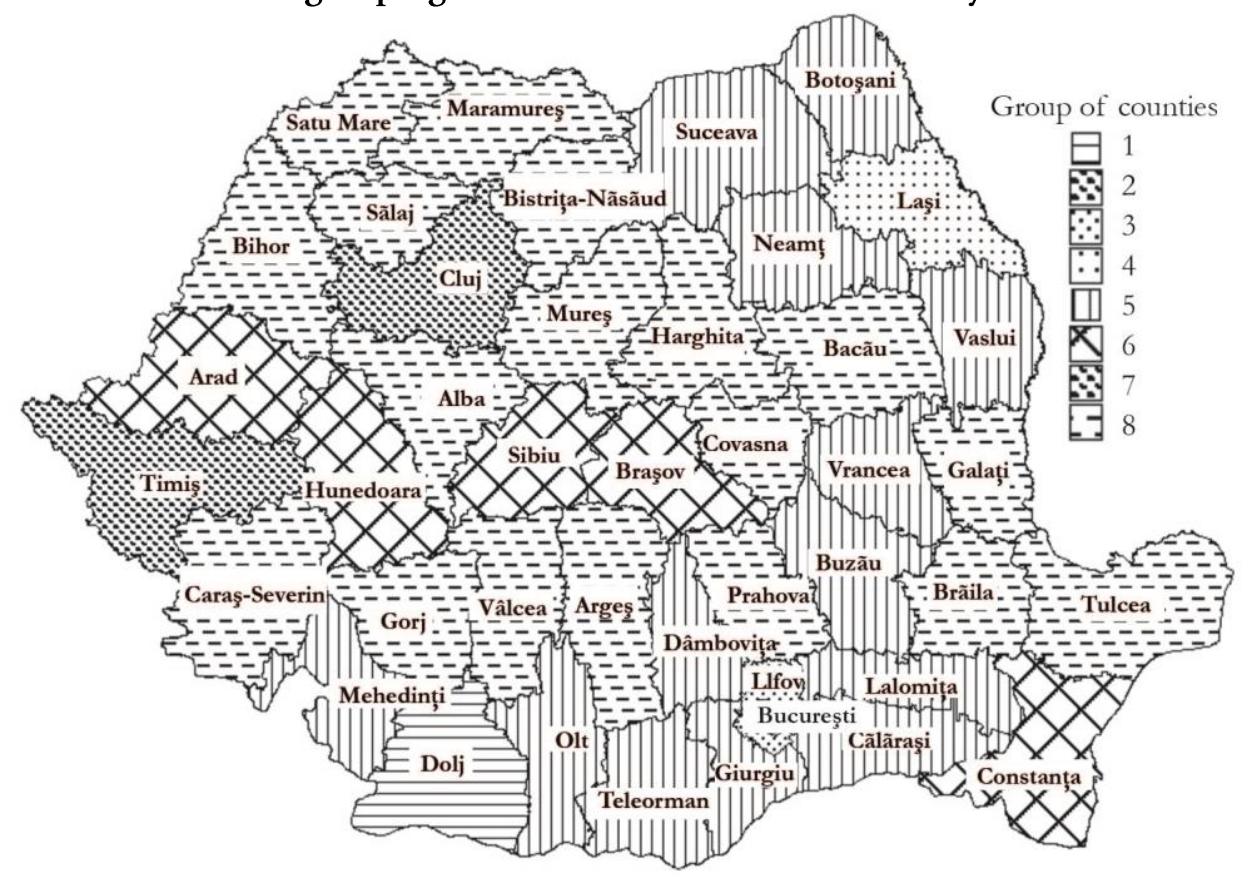

The rest of the counties do not necessarily compose one completely homogeneous cluster, as the distribution of the variables is very random. Thus, going into more detail in the following phase, the separation of Tulcea County can be noted, with a very low level of motorisation and very poor sanitary infrastructure, followed by Caras-Severin County, based on the low percentage of higher education gradu-

Regional Statistics, Vol. 8. No. 1. 2018: 120-140; DOI: 10.15196/RS080105 
ates. The low level of the foreign direct investments contributes to the individualisation of Olt County, followed by the separation of the Harghita and Covasna counties because of the reduced proportion of the population occupied in the R\&D sector. As the counties outside the above-mentioned seven clusters compose a group with a much higher heterogeneity, we will not explain each of them, but this does not mean that they compose a perfectly homogeneous grouping.

Of course, when applying the cluster method, the basic question remains: How do we most efficiently group the counties into development regions? A major shortcoming of the existing development regions may be attributed to their economic diversity, counties with a higher level of economic development being included in the same administrative region as less developed counties (Benedek 2004, 2006, Cörvers et al. 2009). A typical example is the North-West region, where the level of development is negatively affected by the lower economic GDP per capita of counties such as Sălaj and Bistrița-Năsăud. The inverse interpretation is that the high values of GDP per capita of some counties (Argeș or Prahova in SouthMuntenia) are fetishising the difficult situation of less developed counties (Teleorman and Giurgiu in South-Muntenia). Additionally, the peripheral location of some first-rank municipalities (Iaşi, Constanța, Braşov), within the region they belong to, leads to the reduction of their spatial polarisation ability.

Figure 9

The grouping of counties into development regions by complex homogeneity

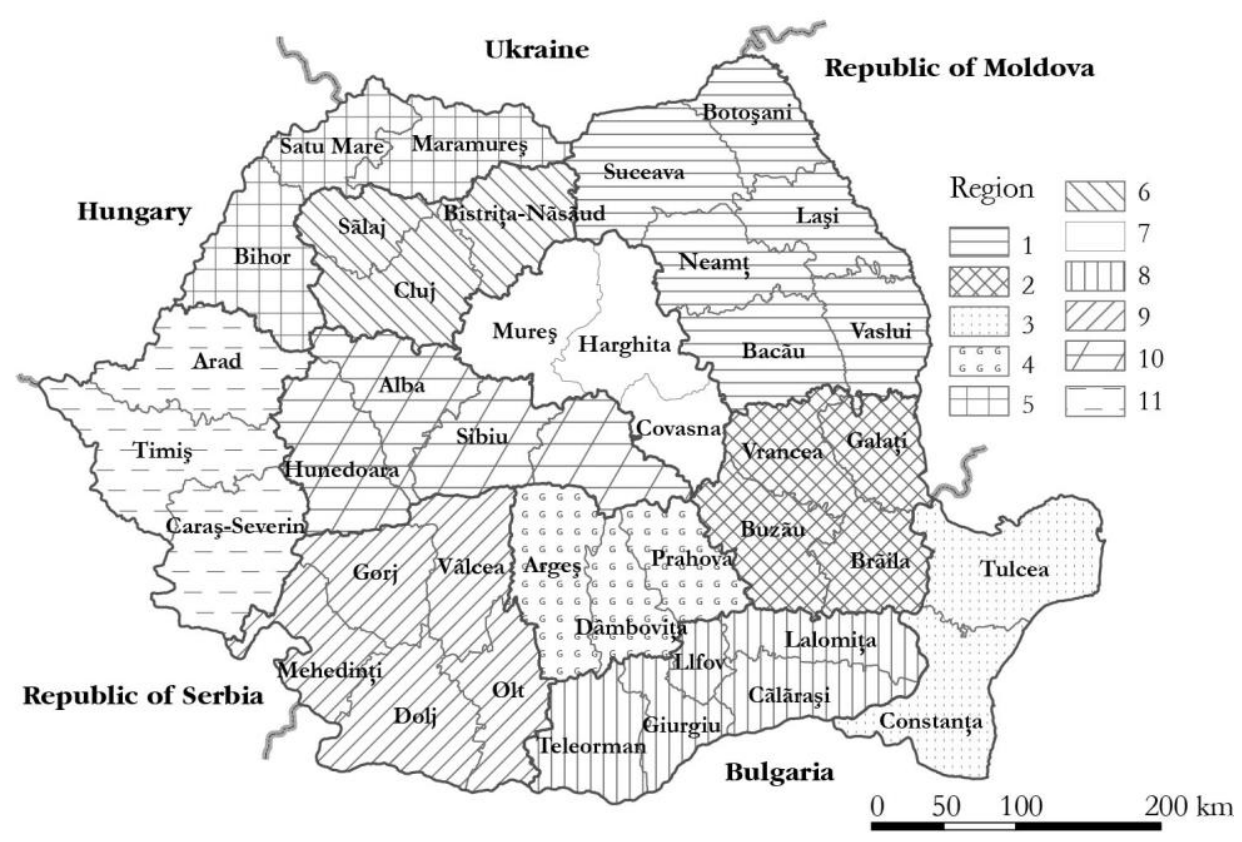

Regional Statistics, Vol. 8. No. 1. 2018: 120-140; DOI: 10.15196/RS080105 
The third and final scenario for the reorganisation of the development regions results from combining the cluster analysis with the determination of the areas of theoretical influence (catchment areas) of the major urban centres. The latter has been determined according to the size and rank of the urban centres (cities over 250,000 inhabitants). All eleven urban centres of rank one have been taken into consideration (for full details, see Benedek et al. 2013). The results are represented by eleven development regions presented in Figure 9. The main argument for this combination is shared with other studies (Andersen 2002, Cörvers et al. 2009, Pálóczi et al. 2016), namely that administrative regions should be based on functional economic regions for policymaking purposes.

Table 3 presents the territorial composition of all three scenarios discussed in this paper. Comparing these scenarios, we can observe some differences in the number of designated regions, from ten for the first scenario (economic homogeneity), to twelve regions for the second scenario (cultural homogeneity). According to the complex homogeneity criteria (third scenario), the resulting eleven regions represent an intermediate situation. We think that the latter has the highest empirical evidence because it is the only one that can be considered as a functional region.

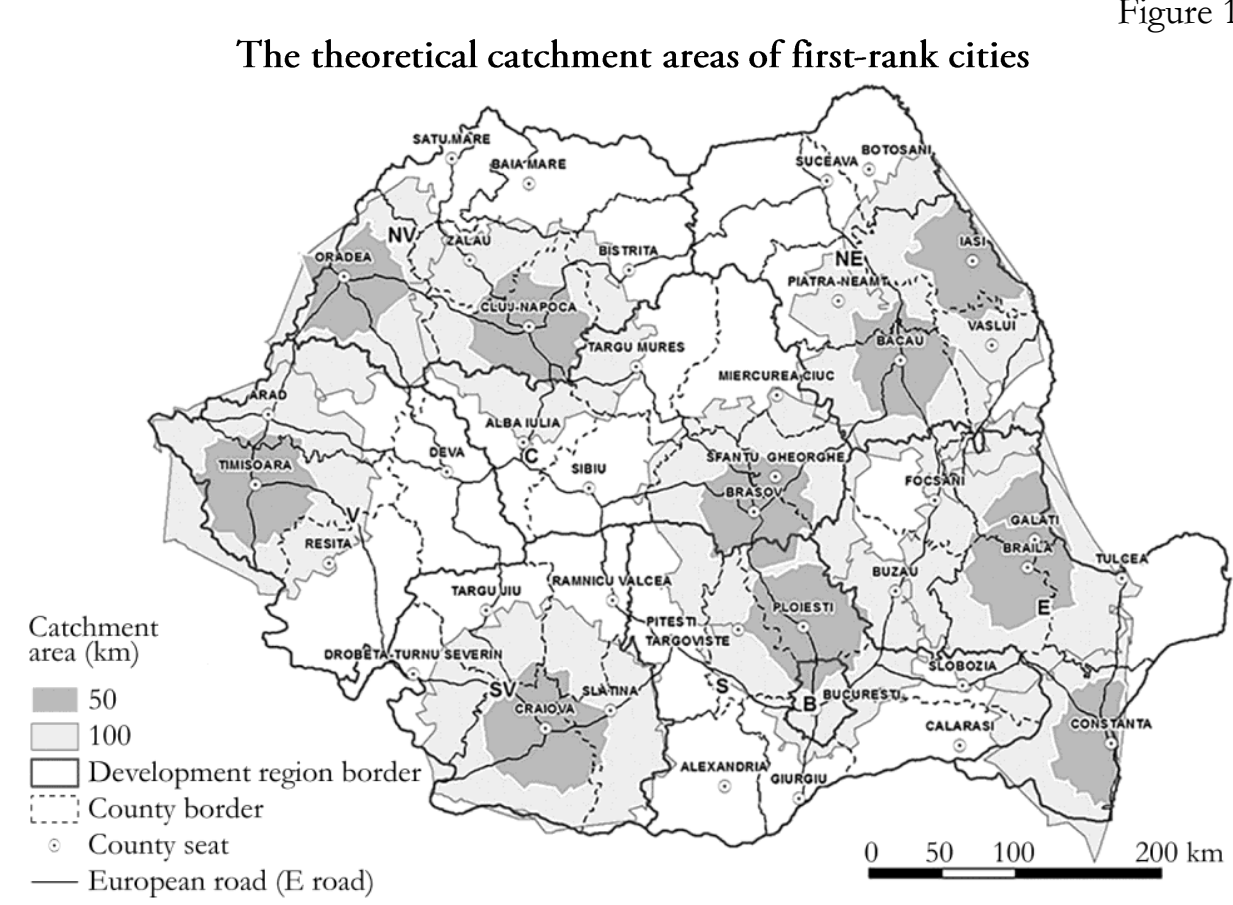

Regional Statistics, Vol. 8. No. 1. 2018: 120-140; DOI: 10.15196/RS080105 
Table 3

The grouping of counties into development regions based on economic, cultural and complex homogeneity/heterogeneity criteria

\begin{tabular}{|c|c|c|c|}
\hline & Scenario I & Scenario II & Scenario III \\
\hline $\begin{array}{c}\text { Number } \\
\text { of re- } \\
\text { gions }\end{array}$ & $\begin{array}{c}\text { Regions with a low degree } \\
\text { of economic homogeneity } \\
\text { (organised as core-periphery } \\
\text { regions) }\end{array}$ & $\begin{array}{l}\text { Regions with a high degree } \\
\text { of cultural homogeneity }\end{array}$ & $\begin{array}{l}\text { Regions with a high degree } \\
\text { of complex homogeneity }\end{array}$ \\
\hline 1 & $\begin{array}{l}\text { Iaşi, Bacău, Suceava, } \\
\text { Botoşani, Neamț, Vaslui }\end{array}$ & $\begin{array}{l}\text { Iaşi, Suceava, Botoşani, Ne- } \\
\text { amţ }\end{array}$ & $\begin{array}{l}\text { Iaşi, Botoşani, Suceava, Ne- } \\
\text { amț, Vaslui, Bacău }\end{array}$ \\
\hline 2 & $\begin{array}{l}\text { Galați, Brăila, Vrancea, } \\
\text { Buzău }\end{array}$ & $\begin{array}{l}\text { Bacău, Galați, Vaslui, } \\
\text { Vrancea }\end{array}$ & $\begin{array}{l}\text { Galați, Brăila, Buzău, } \\
\text { Vrancea }\end{array}$ \\
\hline 3 & $\begin{array}{l}\text { Constanța, Tulcea, Ialomiţa, } \\
\text { Călăraşi }\end{array}$ & $\begin{array}{l}\text { Brăila, Ialomiţa, Călăraşi, } \\
\text { Buzău }\end{array}$ & Constanța, Tulcea \\
\hline 4 & Prahova, Argeş, Dâmbovița & Constanța, Tulcea & Prahova, Dâmboviţa, Argeş \\
\hline 5 & $\begin{array}{l}\text { Timiş, Arad, Caraş-Severin, } \\
\text { Hunedoara }\end{array}$ & Prahova, Argeş, Dâmboviţa & Bihor, Satu Mare, Maramureş \\
\hline 6 & $\begin{array}{l}\text { Bihor, Sălaj, Satu Mare, } \\
\text { Maramureş }\end{array}$ & Bihor, Sălaj, Satu Mare & Cluj, Bistriţa-Năsăud, Sălaj \\
\hline 7 & $\begin{array}{l}\text { Cluj, Sibiu, Alba and Bistrița- } \\
\text { Năsăud }\end{array}$ & $\begin{array}{l}\text { Cluj, Maramureş, Bistrița- } \\
\text { Năsăud }\end{array}$ & Mureş, Harghita, Covasna \\
\hline 8 & $\begin{array}{l}\text { Braşov, Mureş, Harghita } \\
\text { and Covasna }\end{array}$ & $\begin{array}{l}\text { Mureş, Harghita } \\
\text { and Covasna }\end{array}$ & $\begin{array}{l}\text { Bucharest-Ilfov, Călăraşi, } \\
\text { Ialomița, Giurgiu, Teleorman }\end{array}$ \\
\hline 9 & $\begin{array}{l}\text { Bucharest-Ilfov, Teleorman, } \\
\text { Giurgiu }\end{array}$ & $\begin{array}{l}\text { Bucharest-Ilfov, Teleorman, } \\
\text { Giurgiu }\end{array}$ & $\begin{array}{l}\text { Dolj, Olt, Vâlcea, Gorj, } \\
\text { Mehedinți }\end{array}$ \\
\hline 10 & $\begin{array}{l}\text { Gorj, Dolj, Vâlcea, } \\
\text { Mehedinți, Olt }\end{array}$ & $\begin{array}{l}\text { Gorj, Dolj, Vâlcea, Me- } \\
\text { hedinți, Olt }\end{array}$ & $\begin{array}{l}\text { Braşov, Sibiu, Alba, } \\
\text { Hunedoara }\end{array}$ \\
\hline 11 & - & $\begin{array}{l}\text { Braşov, Sibiu, Alba, } \\
\text { Hunedoara }\end{array}$ & Timiş, Arad, Caraş-Severin \\
\hline 12 & - & Timis, Arad, Caraş-Severin & \\
\hline
\end{tabular}

\section{Conclusions}

During the Romanian transition period - particularly in 2013 - many competing scenarios for regionalisation have been launched. The benefit of this paper is that it offers evidence-based solutions to the reorganisation of the development regions. All scenarios presented in this paper are the result of applying tools of spatial analysis. The authors are aware that the solutions proposed cannot be viewed as 'optimal ones' and do not exclude other alternatives. The methods, data, and spatial scale all impose some limits on the scope of the article. Therefore, the quantitative and positivist approach has somehow eluded the options and expectations of the population, of local or regional communities, which may be considered as being crucial in delimiting development regions. We do not underestimate these options, but the frame-

Regional Statistics, Vol. 8. No. 1. 2018: 120-140; DOI: 10.15196/RS080105 
work and scope of the study made it impossible to include this bottom-up perspective. The data used in the study is static and not flow data. This limitation is imposed by the low availability of accurate and actual flow data like commuting. Commuting is considered as an important process contributing to the formation of so-called functional economic regions where the majority of inhabitants work, shop, and live. Therefore, there are arguments to consider commuting areas or labour market areas relevant for the designation of administrative regions (Andersen 2002). In the absence of flow data, we had to estimate the potential of spatial interactions using the potential model for GDP per capita and the distance and population for the theoretical influence zones of the cities. Finally, most data were available only at the NUTS 3 level, so the study had to focus on the county level. The outcome of this is the grouping of counties into development regions. We admit that a more accurate analysis should take into account lower spatial levels. Despite all these limitations, our article contributes twofold to the actual debate on the role of development regions in Romania. First, we have outlined that the best way for designating development regions in Romania is a combination of two perspectives: one rooted in the functional economic differentiation and the other related to the ethnocultural diversity of the country. Second, we have argued in the paper for evidence-based area designation, which relies on the combination of different tools and methods of regional science and spatial analysis.

\section{REFERENCES}

ANDERSEN, A. K. (2002): Are commuting areas relevant for the delimitation of administrative regions in Denmark? Regional Studies 36 (8): 833-844. https://doi.org /10.1080/0034340022000012289

BENEDEK J.-LEMBCKE, A. C. (2017): Characteristics of recovery and resilience in the Romanian regions Eastern Journal of European Studies 8 (2): 95-126.

BenedeK, J. (2004): Amenajarea teritoriului şi dezvoltarea regională Presa Universitară Clujeană, Cluj-Napoca.

BenedeK, J. (2006): Területfejlesztés és regionális fejlódés Presa Universitară Clujeană, ClujNapoca.

BENEDEK, J. (2015): Spatial differentiation and core-periphery structures in Romania Eastern Journal of European Studies 6 (1): 49-61.

BENEDEK, J. (2016): Regionalization projects in Romania: Between promises and realities In: KÁROLYI, E. (ed.): Regions in Europe. Administrative Structures and Territorial Identity Issues pp. 124-146., Joseph Karolyi Foundation, L'Harmattan, Fehérvárcsurgó.

BENEDEK, J.-BAJTAlAn, H. (2015): Recent regionalisation discourses and projects in Romania with special focus on the Székelyland Transylvanian Review of Administrative Sciences 11 (44E): 23-41.

Regional Statistics, Vol. 8. No. 1. 2018: 120-140; DOI: 10.15196/RS080105 
BenedeK, J.-Jordan, P. (2007): Administrative Dezentralisierung, Regionalisierung und Regionalismus in den Transformationsländern am Beispiel Rumäniens Mitteilungen der Österreichischen Geographischen Gesellschaft 149: 81-108.

BENEDEK, J.-KuRKÓ, I. (2012): Convergence or divergence? The position of Romania in the spatial structure of the European Union Transylvanian Review (21) 2: 116-125.

Benedek, J.-TÖRÖK, I.-MÁtHÉ, Cs. (2013) Dimensiunea regională a societățiii, diversitatea etno-culturală şi organizarea administrativ-teritorială în România Studii de atelier, Cercetarea Minorităților Naționale din România, nr. 51., Editura Institutului pentru Studierea Problemelor Minorităților Naționale, Cluj-Napoca.

Bodocan, V. (1997): Geografie politica Editura Presa Universitara Clujeana, Cluj-Napoca.

Cörvers, F.-Hensen, M.-Bongaerts, D. (2009): Delimitation and coherence of functional and administrative regions Regional Studies 43(1): 19-31. https://doi.org /10.1080/00343400701654103

ERTUGal, E.-Dobre, A. M. (2011): Dynamics of regionalisation and the impact of the EU: comparing regional reforms in Romania and Turkey Europe-Asia Studies 63 (7): 1195-1222. https://doi.org/10.1080/09668136.2011.592269

FÜstös, L.-KovÁcs, E.-MeszénA, Gy.-Simonné Mosolygó, N. (2004): Alakfelismerés (Sokváltozós statisztikai módszerek) Új Mandátum Könyvkiadó, Budapest.

Han, J.-Kamber, M. (2004): Adatbányászat. Koncepciók és technikák Panem Könyvkiadó, Budapest.

Hoover, E. M.-Giarratani, F. (1999): An Introduction to Regional Economics West Virginia University, Morgantown. (www.rri.wvu.edu/WebBook).

Keating, M. (2015): The European Dimension of Scottish Constitutional Change Political Quarterly 86 (2): 201-208. https://doi.org/10.1111/1467-923X.12156

LENTZ, S.-MeYER, F.-MiggelbrinK, J.-WAACK, C. (2007): Regionalisierungen: Raumdimensionen in der EU-Politik 2007 Osteuropa 57 (2/3): 117-131.

LINEIRA, R.-CETRA, D. (2015): The independence case in comparative perspective Political Quarterly 86 (2): 257-264. https://doi.org/10.1111/1467-923X.12157

MÁTÉ, G.-NÉDA, Z.-BENEDEK, J. (2011): Spring-block model reveals region-like structures PLOS ONE 6 (2): 1-8. https://doi.org/10.1371/journal.pone.0016518

MuIR, R. (1981): Modern Political Geography MacMillan, London.

NagY, G. (2004): Centrális és periférikus térségek lehatárolása a potenciál-modell felhasználásával. Magyar Földrajzi Konferencia. http://geography.hu/mfk2004/ mfk2004/cikkek/nagy_gabor.pdf (downloaded: 15 May 2013)

National Institute of Statistics (INSSE) (2013): Population and Housing Census: Because Everyone Counts [Online] http://www.recensamantromania.ro/en/, (downloaded: 16 February 2013).

National Institute of Statistics (INSSE) (2013a): Tempo-online database [Online] https://statistici.insse.ro/shop/ (downloaded: 16 February 2013).

Nemes Nagy, J. (2005) (eds): Regionális elemzési módszerek MTA-ELTE Regionális Tudományi Kutatócsoport, Budapest.

PÁlóczi, G.-PÉnzes, J.-Hurbánek, P.-Halás, M.-KlapkA, P. (2016): Attempts to delineate functional regions in Hungary on the basis of commuting data Regional Statistics 6 (2): 23-41. https://doi.org/10.15196/RS06102

Regional Statistics, Vol. 8. No. 1. 2018: 120-140; DOI: 10.15196/RS080105 
PÉNZES, J. (2010): Területi jövedelmi folyamatok az Észak-Alföldi régióban a rendszerváltás után Debreceni Egyetemi Kiadó, Debrecen.

PÉnZEs, J.-TÁTrAi, P.-PÁszTOR, I. Z. (2018): A roma népesség területi megoszlásának változása Magyarországon az elmúlt évtizedekben Területi Statisztika 58 (1): 3-27. https://doi.org/10.15196/TS580101

Rodríguez-Pose, A.-GiLl, N. (2005): On the 'economic dividend' of devolution Regional Studies 39 (4): 405-420. https://doi.org/10.1080/00343400500128390

SăGEATĂ, R. (2004): Modele de regionare politico-administrativă Editura Top Form, Bucureşti.

SZÉKELYI, M.-BARNA, I. (2005): Túlélókészlet az SPSS-hez Typotex Kiadó, Budapest.

Weichart, P. (1996): Die Region - Chimäre oder Strukturprinzip sozialer Systeme?, In: BRUnN, G. (ed.): Region und Regionsbildung in Europa pp. 25-43., BadenBaden, Nomos Verlagsgesellschaft. 